\title{
The Impact of Capital Adequacy, Operating Efficiency, Credit and Asset Management on Profitability Performance of Private Commercial Banks: A Study on Bangladesh
}

\author{
Md. Jahedul Hasan \\ Lecturer, Department of Business Administration, BGC Trust University Bangladesh, \\ PO Box 4370, Mujafforabad, Patia, Chattagram, Bangladesh
}

\begin{abstract}
The purpose of this study is to assess the impact of capital adequacy, operating efficiency, credit and asset management on profitability performance. For this study, a total of 13 Bangladeshi private commercial banks and their annual reports (2015-2019) were considered. Return on assets (ROA) and return on equity (ROE) were used as profitability performance. Descriptive, correlation and multiple regression statistics were used. Correlation results showed that asset management (AM) and credit deposit (CD) were positively and significantly correlated with return on assets (ROA). Regression result revealed that operating efficiency (OE) was negatively significant with return on assets (ROA) and return on equity (ROE). Again credit deposit (CD) was positively significant with return on assets (ROA) and return on equity (ROE). It was also revealed that asset management (AM) was positively significant with return on assets (ROA) and capital adequacy (CA) was insignificant with return on equity (ROE). But a simultaneous significant impact was found on return on assets (ROA) and return on equity (ROE). And recommendations were to manage credit, deposit, capital, expense and asset efficiently and to concentrate on optimizing assets for long run survival in the market.
\end{abstract}

Keywords: Asset management, Capital adequacy, Credit deposit, Operating efficiency, Profitability performance DOI: $10.7176 /$ RJFA/13-2-07

Publication date: January $31^{\text {st }} 2022$

\section{Introduction}

Banking sector is one of the leading financial sectors for a country. It plays an important role in the economic development of a country. To survive in the long run it is needed to analyze the performance of any organization. It helps an organization to identify the strength and shortcomings and to take necessary actions what to do or should be done in the future. Performance evaluation is the important approach for enterprises to give incentive and restraint to their operators and it is an important channel for enterprise stakeholders to get the performance information (Sun, 2011). Good financial performance can provide higher value perception for the company towards the views of the company's stakeholder both internal and external. To be an important part of economy banking sector is needed to be analyzed performance. Liquidity, profitability, efficiency and solvency reports are the financial tools to analyze performance. With analyzing financial performance tools, it is possible to represent how a firm is using its assets and equities and managing liabilities.

This study selected profitability as the performance tool to assess the private commercial banking sector in Bangladesh. A business's long term survival, growth and expansion depend on profitability (Owolobi et al. 2011). Profitability is the most important belief of the majority business entities; hence its comparative significance in the investigation of business enlargement and endurance (Devi \& Devi, 2014). Therefore, there is an important influence of profitability on business.

Profitability means the earning ability of a firm with its acquired resources. The resources are assets and equity. And profitability is measured in terms of return on equity (ROE), return on assets (ROA) and return on investment (ROI) etc. The study selected ROA and ROE as profitability performance and dependent variables. ROAA is most preferred measure of profitability (Noman et al, 2015). ROA shows the profit earned per dollar of assets which reflects bank's management ability to utilize the bank's financial and real investment resources to generate profits (Naceur, 2003). The higher the ROE, the better the position of the owner of the company (Peranangining \& Nusantara, 2019). Thus the decreasing ROE will lead an organization to bankruptcy.

This study assessed the profitability performance by capital adequacy, asset management, operating efficiency and credit deposit and used as independent variables. Deposits, credits, operating expenses, assets, equities etc. are the important elements in the banking sector. Efficient use of deposit, asset, equities and management of credit, operating expenses increase the performance of banks. The more deposits were transformed into loans, the higher the interest margin and profit. Hence, deposits generally had positive impact on profitability of the banks (Islam et al., 2017).Capital (ratio of equity to assets) is very important in explaining bank profitability (Athanasoglou et al., 2006). Credit risk and operating inefficiencies (which signal market power) explain most of the variation in net interest margins (Al- Haschimi, 2007). Operational efficiency and operational effectiveness, which might directly influence the survival of a company (Chien and Danw, 2004). The operational efficiency and 
asset management, in addition to the bank size, strongly and positively influenced financial performance of the banks (Tarawneh, 2006).An efficient asset liability management requires maximizing banks profit as well as controlling and lowering various risks (Tekas et al.2005).Credit deposit ratio and net interest income affect the net profitability significantly (Kedia, 2016). Firm size, both in terms of total assets and in terms of total sales, has a positive impact on the profitability ( Akbas \& Karaduman, 2012). Asset management is needed to improve the profitability of the company (Purba \& Bimantara 2020).

Many previous studies showed an influence of asset management, capital ratio, credit deposit and operational efficiency on profitability performance. In this research, it is hypothesized that the Bangladeshi private commercial banks have an impact of capital adequacy, operating efficiency, credit deposit and asset management on the profitability performance.

This study has eight sections. After introduction, which is provided in section 1 above, literature review is carried out in section 2. The section 3 objectives of the study, Section 4 Research hypothesis, section 5 research methodology, section 6 results and discussion, Section 7 conclusion and finally recommendations are drawn in section 8 .

\section{Literature Reviews}

Generally efficiency means outputs in response to inputs.Within the financial efficiency literature, efficiency is treated as a relative measure which reflects the deviations from maximum attainable output for a given level input (English et. al 1993).

Ho and Zhu (2004) have reported that the evaluation of a company's performance has been focusing the operational effectiveness and efficiency which might influence the company's survival directly. Cost to income (CI) ratio indicates the operational efficiency of the bank indicating the cost of running the bank in compare to its income. Higher the ratio means that bank is operating at low efficiency and at high competition which negatively affects the profitability of the bank Noman et al.(2015).

Capital adequacy refers to the sufficiency of the amount of equity to absorb any shocks that the bank may experience (Kosmidou, 2008). Antwi (2019) examined the relationship between capital adequacy, cost income ratios and performance of banks listed on the Ghana stock exchange for the periods 2013 and ending 2018. The study revealed that capital adequacy and cost Income ratio were negatively related to performance as measured by return on assets (ROA) and return on equity (ROE). Capital adequacy ratio statistically insignificant with ROA and significant with ROE. Cost to Income ratio was statistically significant with ROA and ROE.

Almazari(2013) examined the relationship between capital adequacy, cost-income ratio and bank size of nine Saudi banks listed in the stock exchange market over the period 2007-2011 and found a positive impact of capital adequacy to ROA. Again, cost to Income ratio was found a negative and significant impact on ROA. It was concluded that the essence of capital adequacy enhances the bank profitability and helps in reducing the expected costs of financial distress, including bankruptcy.

Jha \& Hui (2012) used CAMEL model to determine the financial performance of different ownership structured commercial banks in Nepal for the period 2005-2010. Regression model was used to estimate the impact of Capital adequacy ratio, non performing loan ratio, interest expense to total loan, net interest margin ratio and credit to deposit ratio on the financial profitability namely return on assets (ROA) and return on equity (ROE). Estimation result revealed that capital adequacy was negatively and positively related with ROA and ROE respectively. Again Credit deposit ratio was positively and negatively related with ROA and ROE respectively.

Abreau \& Mendes (2001) investigated on commercial banks from four different European Union (EU) countries for the period of 1986-1999 and found a positive and significant relation between capital adequacy and profitability (ROA, ROE). Staikouras \& wood (2004) studied performance of EU banking industry 1994-1998 and suggested that the profitability is influenced not only by Management decision but also to changes in the external macro-economic environment. He found loan to assets and capital adequacy a positive impact on profitability (ROA).

Patni \& Darma (2017) conducted research to know the influence of non-performing loan, loan to deposit ratio, net margin, capital adequacy ratio to return on assets and return on equity of the listed banking companies of the Indonesian stock exchange with financial statement for the period of 2012-2016. It was found the significant and positive impact of capital adequacy ratio and loan to deposit ratio to ROA and ROE. It was expected that non performing loan should be reduced and loan to deposit ratio should be optimized. Batia et al (2012), examined the determinants of profitability in the private sector banks in India for the years 2006-07 to 2009-2010 and found that credit to deposit ratio affect profitability significantly. It was suggested that if banks concentrated on the variables used, they would have been able to generate better profitability in the present globalized era. Bodla \& Verma (2006) in their study of multivariate analysis found positive relation between credit deposit ratio and profit. Samad (2015) examined the impact of bank specific characteristics and macroeconomic variables in determining the banks' profitability of Bangladeshi banking industry with a panel data of 42 Bangladeshi commercial banks' financial reports. Results found a significant and positive impact of loan-deposit ratio, equity capital to total assets on ROA. 
Akhtar et al. (2011) used multivariate regression model in his study and found significant and positive impact of capital adequacy ratio to profitability whereas asset management was statistically significant with ROA and insignificant with ROE. Purba \& Bimantara (2020) used panel data analysis to determine the effect of asset Management of six companies in the period 2013-17 and found a significant and positive impact on return on assets (ROA).

The literature indicates that a lot of research has been done. Capital adequacy, credit deposit, asset management and operating efficiency were used as independent variables to determine the impact on profitability performance. ROE and ROA were used as profitability performance in the previous studies. But no more all four variables were used together in the previous studies to determine profitability performance. This research will fill this literature gap. This research will also add an additional implication to the previous research

\section{Objectives of the Study}

The Objectives of the study:

i) assessing the impact of capital adequacy, operating efficiency, credit deposit and asset management on profitability performance

ii) investigating the relationship of capital adequacy, operating efficiency, credit deposit and asset management on profitability performance.

iii) investigating how well banks are using its resources such as equity, deposits and assets.

\section{Research Hypotheses}

Following are the research hypotheses of the study:

H1: There is partial impact of operating efficiency (OE), asset management (AM), capital adequacy (CA) and credit deposit (CD) on return on assets (ROA) and return on equity ROE).

$\mathrm{H} 2$ : There is simultaneous impact of operating efficiency (OE), asset management (AM), capital adequacy (CA) and credit deposit (CD) on return on assets (ROA) and return on equity ROE).

\section{Methodology of the Study}

The purpose of this study is to assess the impact of capital adequacy (CA), asset management (AM), operating efficiency $(\mathrm{OE})$ and credit deposit $(\mathrm{CD})$ on profitability performance. To assess the impact on profitability performance, a total of 13 private commercial banks that are listed in the stock exchange of Bangladesh Securities and Exchange Commission (BSEC) were selected. Annual reports published during 2015-2019 by the selected commercial banks were taken as the source of data. In addition, other source of data such as review of different articles, papers and relevant previous studies were collected and studied. The whole data were secondary type. The independent variables are used as follows:

i) Operating efficiency which is measured by Operating expenses to operational income

ii) Asset management which is measured by total revenue to total assets

ii) Capital adequacy which is measured by equity to asset

iv) Credit deposit which is measured by credit to deposit.

And dependent variables as profitability performance are used as follows:

i) Return on assets which is measured by net income after tax to average total assets

ii) Return on equity which is measured by net income after tax to total shareholders' equity.

Descriptive, correlation and multiple regression statistics were used to assess the probability. IBM SPSS statistics (Version: 28) is used for statistical calculations.

\section{Results and Discussion}

\subsection{Descriptive Statistics}

The table 1 provides the summary Statistics for the variables that are used in analysis. The mean value of ROA and ROE is 0.95 and 11.98 respectively where standard deviation is 0.21 and 2.59 respectively. Maximum value is 1.36 and 16.28 for ROA and ROE respectively. Minimum value is 0.68 and 7.46 for ROA and ROE respectively. The positive skewness of ROA indicates that maximum banks are earning lower ROA than the average. It means maximum bank's performance is not good in terms of ROA comparing with industry average. It also indicates asset level is higher than the optimum. A negative skewness of ROE indicates that maximum banks are earning higher ROE than the average. It means maximum bank's performance is good in terms of ROE comparing with industry average.

\subsection{Correlation}

The table (2) shows the correlation among the dependent and independent variables. Credit deposit and asset management are positively correlated with ROA and ROE but significant with ROA at $5 \%$ level of significance. Operating efficiency is negatively correlated with ROA and ROE but not significant. Capital adequacy is positively 
and negatively correlated respectively with ROA and ROE. Only two variables are found here significant, hence multiple regressions are followed.

\subsection{Regression analysis}

Table 3 and 4 presents the regression result for the Model of ROA and ROE.

\subsubsection{Testing Hypothesis (ROA)}

i) The $t$ value (4.079) of credit deposit (CD) indicates that there is a positive relation between CD and ROA and fund collected as deposit by the banks are used efficiently and contributing to earning profit. The result is consistent with Kedia (2016), Batia (2012), Samad (2015) and reversed to Jha \& Hui (2012). The p value (0.004) of CD indicates it has significant impact on ROA. Therefore null hypothesis is rejected. And CD has partial impact on ROA at $1 \%$ level of significance

ii) The $t$ value (1.395) of capital adequacy (CA) indicates that there is a positive relation between CA and ROA and there is a good combination of equity in relation to assets. It also means that if a good combination between equity and assets is possible, a good profitability performance is increased. The result is consistent with Almazari (2013), Abreau \& Mendes (2002), Samad (2015) and Staikouras \& Wood (2004). But the finding is reversed with Antwi (2019), JHa \& Hui (2012). The p value (0.20) of CA indicates that the relationship is not significant between CA and ROA. Therefore null hypothesis is accepted. And CA has no partial impact on ROA at $5 \%$ level of significance.

iii) The $t$ value (3.544) of asset management (AM) indicates there is a positive relation between AM and ROA. It means assets are managed efficiently. It also indicates if assets are used efficiently to earn revenue, a good profitable performance is possible. The result is consistent with Purba \& Bimantara (2020), Akhtar et.al. (2011).The $p$ value (0.008) of AM indicates that it has significant impact on ROA. Therefore null hypothesis is rejected. And AM has partial impact on ROA at 1\% level of significance.

iv) The $t$ value $(-3.477)$ of operating efficiency $(\mathrm{OE})$ indicates that there is a negative relation between $\mathrm{OE}$ and ROA. It means expenses are managed efficiently. It also indicates that lower the expenses, the higher the return and results to a good profitable performance. This is consistent with Antwi (2019), Almazari (2013).The $\mathrm{p}$ value (0.008) of OE indicates it has significant impact on ROA. Therefore null hypothesis is rejected. And OE has partial impact on ROA at $1 \%$ level of significance.

v) The value of adjusted R square 0.834 indicates that ROA is affected by the predictive variables with $83.4 \%$.

vi) The value of Durbin Watson 2.51 indicates that there is a negative auto correlation. The VIF values are less than 10 and tolerance values are greater than 0.1 .Therefore no multi co-linearity exists.

vii) The $\mathrm{F}$ value is 16.048 where $\mathrm{p}$ value is 0.00 which is less than $1 \%$ indicates that simultaneously predictive variables have significant impact on ROA at $1 \%$ level of significance. Therefore $\mathrm{H} 2$ is accepted.

6.3.2. Testing Hypothesis Testing (ROE)

i) The $t$ value (2.664) of credit deposit (CD) indicates that there is a positive relationship between CD and ROE. This is an added implication to profitability performance (ROA) of this research. The result is consistent with Kedia (2016), Batia (2012), Bodla \& Verma (2006), Patni and Drama (2017) and reversed with Jha \& Hui (2012). CD has significant impact on ROE because $\mathrm{p}$ value is 0.029 . Therefore null hypothesis is rejected. And CD has partial impact on ROE at 5\% level of significance.

ii) The t value (-4.349) of capital adequacy (CA) indicates a negative relationship between CA and ROE. This is the reversed finding to profitability performance (ROA) of this research. The negative relationship indicates that if capital adequacy is reduced profitability performance will be increased. This is the cause of higher assets of the banks. The result is consistent with Antwi (2019). The finding is reversed with Jha \& Hui (2012), Abreau \& Mendes (2002), Patni and Drama (2017). For p value $\backslash(0.002)$, null hypothesis is rejected. Therefore an insignificant partial impact exists at $1 \%$ level of significance.

iii) The $t$ value (2.167) of asset management (AM) indicates a positive relationship between AM and ROE. This is also an added implication to profitability performance (ROA) of this research. The finding is consistent with Akhtar et al.(2011). For $\mathrm{p}$ value 0.062 , null hypothesis is accepted. Therefore AM has no partial impact on ROE at $5 \%$ level of significance.

iv) The $t$ value (-2.741) of operating efficiency (OE) indicates a negative relationship between OE and ROE. This is another added implication to profitability performance (ROA) of this research. The finding is consistent with Antwi (2019). For $\mathrm{p}$ value (0.025), null hypothesis is rejected. And operating efficiency has partial impact on ROE at $5 \%$ level of significance.

V) The value (0.70) of adjusted R square indicates the ROE is affected by the predictive variables with $70 \%$.

vi) The value (2.44) of Durbin Watson indicates a negative autocorrelation. The tolerance values are greater than 0.1 and VIF values are less than 10 . Therefore no multi-co linearity exists.

vii) The $\mathrm{F}$ value is 7.995 where $\mathrm{p}$ value is 0.01 indicates that simultaneously predictive variables have a significant impact on ROE at $1 \%$ level of significance. Therefore $\mathrm{H} 2$ is accepted. 


\section{Conclusion}

The aim of this study is to measure the impact of operating efficiency, asset Management, Capital adequacy and credit deposit on profitability performance. Return on assets and return on equity were used as profitability performance. Different and same results were found from the two profitability performance model. Descriptive statistics showed asset level of maximum banks is higher than optimum.

In correlation statistics, asset management and credit deposit were found positive and significant correlation with ROA. Also a positive correlation was found with ROE but not significant. Operating efficiency was found negative correlation with ROA and ROE. But there was a reverse correlation found in case of capital adequacy, because capital adequacy was positively and negatively correlated with profitability performance (ROA \& ROE) respectively.

Regression statistics revealed that the impact of credit deposit was positively and operating efficiency was negatively significant with profitability performance (ROA \& ROE). Capital adequacy was positive and not significant with profitability performance (ROA) but was insignificant impact on profitability performance (ROE). Again, asset management was positive impact on profitability performance (ROA \& ROE) but significant with ROA. For both model of profitability performance (ROA \& ROE) a simultaneous significant impact was found.

\section{Recommendations}

The following recommendations are drawn:

i) The study proved that there is a significant impact of credit, capital, expense and asset management on profitability performance. Hence, they are to be managed by the bank regulators efficiently.

ii) Analysis revealed that the banks having larger assets earning lower profit. The bank regulators should concentrate on optimizing assets for long run survival in the market.

iii) This study cannot avoid its limitation that the study was completed with only 13 banks, 5 years annual financial report and four predictive variables. Moreover Govt., Islamic and specialized banks of Bangladesh was not considered. The suggestions are to the future researchers to analyze more deeply by extending the duration of annual financial report, sample and predictive variables such as board size, sustainability banking, cost of fund, non-performing loan and corporate social responsibility etc. It is also suggested to conduct research on taking into consideration Govt., Islamic and specialized banks of Bangladesh.

\section{References}

Abreu, M. \& Mendes, V. (2001). Commercial bank interest margins and profitability. Pan-European Conference Jointly Organized by the IEFS-UK \& University of Macedonia Economic \& Social Sciences, Thessaloniki, Greece, May 34 (2), 17-20.

Akbas,H.E. \& Karaduman, H.A. (2012).The effect of firm size on profitability: An empirical investigation on Turkish manufacturing companies. European Journal of Economics, Finance and Administrative Sciences $55,21-27$,

Akhtar, M. F., Ali, k. \& Sadaqat, S. (2011). Factors influencing the profitability of Islamic banks of Pakistan. International Research Journal of Finance and Economics, 66,125-132.

Al-Hashimi, A. (2007). 'Determinants of Bank Spreads in Sub-Saharan Africa', draft.

Almazari, A. (2013). Capital adequacy, cost income ratio and the performance of Saudi banks (20072011).International Journal of Academic Research in Accounting, Finance and Management Sciences, 3(4), 284-293.

Antwi, F. (2019). Capital adequacy, cost income ratio and performance of banks in Ghana. The International Journal of Academic Research in Business and Social Sciences, 9(10):168-184.

Athanasoglou, Panayiotis P., Delis, Manthos D. \& Staikouras, C.K. (2006). Determinants of bank profitability in the South Eastern European Region. Journal of Financial Decision Making, 2, 1-17.

Batia, A., Mahajan, P. \& Chander, S. (2012). Determinants of profitability of private sector banks in India. Indian Journal of Accounting, 42 (2), 39-51.

Bodla,B.S. \& Verma, M. R. (2006). Determinants of profitability of Banks in India: A multivariate analysis. Journal of Services Research, 6(2).

Chien, T. \& Danw, S. Z. (2004). Performance measurement of Taiwan commercial banks. International Journal of Productivity and Performance Management, 53(5), pp. 425-434.

Devi, A. \& Devi, S. (2014). Determinants of profitability in Pakistan. Research Journal of Finance and Accounting, 5(19), 87-91.

English, M. \& Grosskopf, K., \& Hayes, K. (1993). Output allocative and technical efficiency of banks.Journal of Banking and Finance, 17(2-3), 349-366

Ho, C. \& Zhu, D. (2004).performance measurement of Taiwan commercial banks. International Journal of productivity and Performance Management, 53(5), 425-434.

Islam, M. A., Sarker, M. N.I., Rahman, M., Sultanan, A., \& Prodahan, A.S., (2017). Determinants of profitability 
of commercial Banks in Bangladesh. International Journal of Banking and Financial Law, 1(1), 001-011

Jha, S. \& Hui, X. (2012). A comparison of financial performance of commercial banks: A case study of Nepal. African Journal of Business Management, 6(25), 7601-7611.

Kedia, N. (2016). Determinants of profitability of Indian public sector banks. IRA-International Journal of Management \& Social Science, 2(3):1-16.

Koasmidou, K. (2008). The determinants of banks profit in Greece during the period of EU financial Integration. Management and Finance, 34(3),146-159.

Naceur,S.B.,(2003). The determinants of Tunisian banking industry: A panel evidence. Universite Libre de Tunis working papers 10.

Noman, A.H.M., Pervin,S., Chowdhury,M.M. \& Banna,H.,(2015). The effect of bank specific and macroeconomic determinants of banking profitability. International Journal of Business and Management, 10(6), 287-297.

Owolab, A.S., Obikor,R., \& Okwu, A.T. (2011). Investigating liquidity-profitability relationship in business organizations: A study selected quoted companies in Nigeria. British Journal of Economics, Finance and Management Sciences, 1(2): 11-29

Peranginangin, A.M.,\& Nusantara, S.S.(2019). The effect of profitabilty, debt Policy and firm size on company value in consumer goods companies. Abstract Proceedings international Scholars Conference, 7(1), 12171229.

Patni, S. S. \& Darma, G.S. (2017). Non performing loan, loan to deposit ratio, net interest margin, BOPO, Capital adequacy ratio, return on assets and return on equity. Journal Manajemen dan bisnis, 14(2), 166-184.

Purba, J.H.V. \& Bimantara, D.(2019). The influence of asset management on financial performance with panel data analysis. Advances in Economics, Business and Management Research, 143,150-155.

Samad, A. (2015). Determinants bank profitability: Empirical evidence from Bangladeshi commercial banks. International journal of financial research, 6 (3), 173-179.

Staikouras , C.K., \& Wood, E.G. (2004). The determinants of European bank profitability. International Business and Economics Journal, 3(6), 57-68.

Sun, C.C. (2011). Assessing Taiwan financial holdings companies' performance using window analysis and Malmquist productivity index. African Journal of Business and Management, 5(26),10508-10523.

Tarawneh, M. (2006). A Comparison of financial performance in the banking Sector: Some Evidence from Omani commercial banks.International Research Journal of Finance and Economics, (3), 101-112

Tekas, A., Okan-gunay, E.N. \& Gunay, G.(2005). Asset and liability management in financial crisis. The Journal of Risk Finance, 6(2), 135-149.

Table 1: Descriptive Statistics

\begin{tabular}{|l|c|c|c|c|c|c|c|c|}
\hline & Minimum & Maximum & Mean & Std. Deviation & \multicolumn{2}{|c|}{ Skewness } & \multicolumn{2}{|c|}{ Kurtosis } \\
\cline { 6 - 9 } Variables & Statistic & Statistic & Statistic & Statistic & Statistic & Std. Error & Statistic & Std. Error \\
\hline CD & 86.45 & 104.17 & 93.4346 & 5.26064 & 1.181 & 0.616 & 1.059 & 1.191 \\
\hline CA & 5.11 & 11.38 & 7.8015 & 1.58064 & 0.454 & 0.616 & 1.350 & 1.191 \\
AM & 8.64 & 10.64 & 9.6292 & 0.52554 & 0.073 & 0.616 & 0.327 & 1.191 \\
\hline OE & 38.00 & 55.00 & 47.1538 & 5.45964 & -0.106 & 0.616 & -1.271 & 1.191 \\
\hline ROA & 0.68 & 1.36 & 0.9595 & 0.20703 & 0.828 & 0.616 & -0.247 & 1.191 \\
ROE & 7.46 & 16.28 & 11.9808 & 2.58714 & -0.111 & 0.616 & -0.773 & 1.191 \\
\hline Valid N & 13 & 13 & 13 & 13 & 13 & 13 & 13 & 13 \\
\hline
\end{tabular}

Source: IBM SPSS Statistics (Version: 28) 
Table 2: Correlation Matrix

\begin{tabular}{|c|c|c|c|c|c|c|c|}
\hline Variables & & CD & CA & AM & OE & ROA & ROE \\
\hline \multirow{3}{*}{ CD } & Pearson Correlation & 1 & 0.268 & 0.377 & 0.379 & $.657^{*}$ & 0.276 \\
\cline { 2 - 8 } & Sig. (2-tailed) & & 0.375 & 0.205 & 0.201 & 0.015 & 0.360 \\
& Pearson Correlation & 0.268 & 1 & -0.037 & -0.253 & 0.460 & -0.529 \\
\cline { 2 - 8 } & Sig. (2-tailed) & 0.375 & & 0.906 & 0.404 & 0.114 & 0.063 \\
\hline \multirow{3}{*}{ OE } & Pearson Correlation & 0.377 & -0.037 & 1 & 0.133 & $.618^{*}$ & 0.540 \\
& Sig. (2-tailed) & 0.205 & 0.906 & & 0.665 & 0.024 & 0.057 \\
\cline { 2 - 8 } & Pearson Correlation & 0.379 & -0.253 & 0.133 & 1 & -0.236 & -0.057 \\
\cline { 2 - 8 } & Sig. (2-tailed) & 0.201 & 0.404 & 0.665 & & 0.437 & 0.853 \\
\cline { 2 - 8 } & Pearson Correlation & $.657^{*}$ & 0.460 & $.618^{*}$ & -0.236 & 1 & 0.464 \\
\cline { 2 - 8 } & Sig. (2-tailed) & 0.015 & 0.114 & 0.024 & 0.437 & & 0.110 \\
\hline \multirow{2}{*}{ ROE } & Pearson Correlation & 0.276 & -0.529 & 0.540 & -0.057 & 0.464 & 1 \\
\cline { 2 - 8 } & Sig. (2-tailed) & 0.360 & 0.063 & 0.057 & 0.853 & 0.110 & 13 \\
\hline
\end{tabular}

Source: IBM SPSS Statistics (Version: 28)

*Correlation is significant at the 0.05 level (2tailed).

Table 3: Regression statistics (Model: ROA)

\begin{tabular}{|c|c|c|c|c|c|c|c|}
\hline \multirow[t]{2}{*}{ Model(ROA) } & \multicolumn{2}{|c|}{$\begin{array}{l}\text { Unstandardized } \\
\text { Coefficients }\end{array}$} & \multirow{2}{*}{\begin{tabular}{|c|}
$\begin{array}{l}\text { Standardized } \\
\text { Coefficients }\end{array}$ \\
Beta \\
\end{tabular}} & \multirow[t]{2}{*}{$\mathrm{t}$} & \multirow[t]{2}{*}{$\mathrm{p}$} & \multicolumn{2}{|c|}{ Co-linearity Statistics } \\
\hline & $\mathrm{B}$ & Std. Error & & & & Tolerance & VIF \\
\hline (Constant) & -2.372 & 0.539 & & -4.399 & 0.002 & & \\
\hline $\mathrm{CD}$ & 0.024 & 0.006 & 0.617 & 4.079 & 0.004 & 0.605 & 1.653 \\
\hline $\mathrm{CA}$ & 0.025 & 0.018 & 0.189 & 1.395 & 0.200 & 0.757 & 1.320 \\
\hline AM & 0.180 & 0.051 & 0.457 & 3.544 & 0.008 & 0.832 & 1.201 \\
\hline $\mathrm{OE}$ & -0.018 & 0.005 & -0.484 & -3.477 & 0.008 & 0.716 & 1.398 \\
\hline $\mathrm{R}$ & \multicolumn{2}{|c|}{0.94} & & \multicolumn{2}{|c|}{ Durbin Watson } & \multicolumn{2}{|c|}{2.51} \\
\hline R Square & \multicolumn{2}{|c|}{0.88} & & \multicolumn{2}{|c|}{ F value } & \multicolumn{2}{|c|}{16.048} \\
\hline Adjusted R S & \multicolumn{2}{|c|}{0.834} & & \multirow{2}{*}{\multicolumn{2}{|c|}{$\mathrm{p}$-value }} & \multirow{2}{*}{\multicolumn{2}{|c|}{0.00}} \\
\hline S.E. of the es & \multicolumn{2}{|c|}{0.0834} & & & & & \\
\hline
\end{tabular}

\section{Source: IBM SPSS Statistics(Version:28)}

Table 4: Regression statistics (Model: ROE)

\begin{tabular}{|c|c|c|c|c|c|c|c|}
\hline \multirow[t]{2}{*}{ Model(ROE) } & \multicolumn{2}{|c|}{$\begin{array}{l}\text { Unstandardized } \\
\text { Coefficients }\end{array}$} & \multirow{2}{*}{$\begin{array}{c}\begin{array}{l}\text { Standardized } \\
\text { Coefficients }\end{array} \\
\text { Beta } \\
\end{array}$} & \multirow[t]{2}{*}{$\mathrm{t}$} & \multirow[t]{2}{*}{$\mathrm{p}$} & \multicolumn{2}{|c|}{ Co-linearity Statistics } \\
\hline & $\mathrm{B}$ & Std. Error & & & & Tolerance & VIF \\
\hline (Constant) & -9.169 & 9.056 & & -1.013 & 0.341 & & \\
\hline $\mathrm{CD}$ & 0.266 & 0.100 & 0.542 & 2.664 & 0.029 & 0.605 & 1.653 \\
\hline $\mathrm{CA}$ & -1.294 & 0.297 & -0.790 & -4.349 & 0.002 & 0.757 & 1.320 \\
\hline AM & 1.849 & 0.853 & 0.376 & 2.167 & 0.062 & 0.832 & 1.201 \\
\hline $\mathrm{OE}$ & -0.243 & 0.089 & -0.513 & -2.741 & 0.025 & 0.716 & 1.398 \\
\hline \multicolumn{4}{|c|}{$\begin{array}{ll}\mathrm{R} & 0.894\end{array}$} & \multicolumn{4}{|c|}{ F value $\quad 7.995$} \\
\hline \multicolumn{3}{|c|}{ R Square $\quad 0.80$} & & \multicolumn{4}{|c|}{ Durbin Watson 2.44} \\
\hline \multirow{2}{*}{\multicolumn{3}{|c|}{$\begin{array}{ll}\text { Adjusted R Square } & 0.70 \\
\text { S F }\end{array}$}} & & \multirow{2}{*}{\multicolumn{2}{|c|}{ p-value }} & 01 & \\
\hline & & & & & & & \\
\hline
\end{tabular}

\section{Source: IBM SPSS Statistics (version:28)}

